\title{
Ovariectomy-Evoked Increase in Gonadotropin Releasing Hormone Receptor Parallels Its Messenger RNA Level, but Does not Correlate with Stimulated Gonadotropin Release
}

\author{
Suguru SAITO, SHun-ICHIRo IZUMI, MASAaKi KOBAYASHI*, ShigeHARu SAITOH*, \\ TSUNEHISA MAKINO**, YASUNORI YOSHIMURA, SHIRO NOZAWA, AND KEN TAKAMATSU* \\ Department of Obstetrics and Gynecology, School of Medicine, Keio University, Tokyo 160, \\ *Department of Physiology, School of Medicine, Toho University, Tokyo 143, and \\ **Department of Obstetrics and Gynecology, School of Medicine, Tokai University, Kanagawa 259-11, Japan
}

\begin{abstract}
The amount of gonadotropin releasing hormone receptor (GnRH-R) in the anterior pituitary changes during the rat estrous cycle; in addition, it is chronically increased for several weeks in response to ovariectomy. The present study was undertaken to investigate these changes in relation to the concentrations of GnRH-R mRNA, gonadotropins and luteinizing hormone- $\beta$ (LH- $\beta$ ) subunit in serum and the pituitary gland, as well as hypothalamic GnRH. GnRH-R concentrations on the day of estrus were significantly lower than that at diestrus ( $30 \%$ lower during $2 \mathrm{~d}$ ), its mRNA decreased even further (by $60 \%$ ), but there were no significant changes in gonadotropin. Ovariectomy increased GnRH-R significantly (by $30 \%$ during $2 \mathrm{wk}$ ) in parallel with receptor mRNA and with pituitary LH and LH- $\beta$, but induced an earlier increase in serum gonadotropins. Our results suggest that transcriptional activity is more intimately linked to the number of GnRH-R in the long-term increase after ovariectomy than in the short-term change during the estrous cycle, and that the increased GnRH-R is not a major factor in ovariectomy-stimulated gonadotropin release.
\end{abstract}

Key words: mRNA of GnRH-receptor, GnRH, LH, FSH, LH- $\beta$ subunit, ovariectomized rat, estrous cycle, anterior pituitary, hypothalamus

(Endocrine Journal 43: 139-143, 1996)

THE NUMBER of pituitary gonadotropin releasing hormone receptors (GnRH-R) changes during the rat estrous cycle $[1,2]$ and is chronically increased for several weeks by ovariectomy [3]. The short-term changes during estrous, as well as the long-term changes following ovariectomy, could theoretically involve modification of gene transcription, RNA processing or stability, translation, and/

Received: September 28, 1995

Accepted: October 31, 1995

Correspondence to: Dr. Shun-ichiro IZUMI, mailing address: Department of Obstetrics and Gynecology, Nippon Kokan Hospital, 1-2-1 Kokan-dori, Kawasaki-ku, Kawasaki 210, Japan or receptor degradation or internalization. Recently, GnRH-R cDNAs have been cloned from the rat [4] and other species [5, 6]. We undertook the present study to investigate changes in the number of GnRH-R and the receptor mRNA concentrations in the anterior pituitary of ovariectomized rats, in comparison with those in the estrous cycle. In addition, we measured serum and pituitary concentrations of the gonadotropins and luteinizing hormone- $\beta$ (LH- $\beta$ ) subunit, as well as hypothalamic content of $\mathrm{GnRH}$ and analyzed their relationship to the number of GnRH-R. 


\section{Materials and Methods}

\section{Animals and tissue preparation}

Female Sprague-Dawley rats (8-10 weeks old; Shizuoka Laboratory Animal Center, Hamamatsu, Japan) were maintained on a $12 \mathrm{~h}$ light/ $12 \mathrm{~h}$ dark regimen with food and water ad libitum. Ovariectomy was carried out via a dorsal approach on animals lightly anesthetized with ether in the morning of diestrus. Ovariectomized rats were decapitated 1, 2, 3 or $4 \mathrm{wk}$ after the operation. Intact rats were also decapitated at $1800 \mathrm{~h}$ on the day of diestrus or estrus. Estrus and diestrus were confirmed previously, following three consecutive normal 4-day estrous cycles, as assessed by vaginal cytology. The anterior pituitaries were rapidly separated and stored in liquid nitrogen for Northern blot analysis and GnRH-R-binding assay. To analyze hormonal tissue content, the anterior pituitaries and hypothalami were rapidly separated by the method of Ojeda [7] and immediately homogenized with $0.1 \mathrm{~N} \mathrm{HCl}$ at $4{ }^{\circ} \mathrm{C}$. The homogenates were centrifuged at $1,000 \times \mathrm{g}$ for $10 \mathrm{~min}$ at $4{ }^{\circ} \mathrm{C}$, and the supernatants were stored at $-20^{\circ} \mathrm{C}$ until use. Serum samples were obtained from the trunk blood and stored at $-20^{\circ} \mathrm{C}$.

\section{Northern blot analysis}

Individual anterior pituitaries were homogenized with 10 volumes of guanidinium thiocyanate solution; poly (A) ${ }^{+}$RNA was isolated on oligo (dT)-cellulose columns supplied with a Quick Prep ${ }^{\circledR}$ Micro mRNA Purification Kit (Pharmacia Biotech Japan, Tokyo, Japan). An aliquot of poly (A)+ RNA ( $2 \mu \mathrm{g}$ per lane) was electrophoresed on $1 \%$ agarose gels containing formaldehyde and transferred to nylon membranes by capillary action.

Polymerase chain reaction (PCR) was performed between residues 37-266 of rat GnRH-R cDNA [8] using one $\mu \mathrm{g}$ of cDNA reverse-transcribed from rat anterior pituitary poly (A)+ RNA. The PCR product was sequenced and was labeled by a multipriming method [9]. Hybridization was performed for $20 \mathrm{~h}$ at $42{ }^{\circ} \mathrm{C}$ in a solution containing $50 \%$ formamide, $5 \times \mathrm{SSPE}, 250 \mu \mathrm{g} / \mathrm{ml}$ denatured salmon sperm DNA, $5 \times$ Denhardt's solution, $0.1 \%$ SDS and an $\left[\alpha-{ }^{32} \mathrm{P}\right] \mathrm{dATP}$-labeled probe. The filter was washed in $0.1 \times \mathrm{SSC}$ containing $0.1 \%$ SDS at $50{ }^{\circ} \mathrm{C}$ and subjected to autoradiography at $-80{ }^{\circ} \mathrm{C}$ for $96 \mathrm{~h}$ with an intensifying screen. After dehybridization, the same filter was assessed by hybridization with an [ $\left.\alpha-{ }^{32} \mathrm{P}\right] \mathrm{AATP}-$ labeled rat $\beta$ actin cDNA probe [10], to normalize the GnRH-R mRNA levels. Densitometry of the Northern blots was done with a computerized image scanner (AE6900, Atto Co., Tokyo, Japan). The GnRH-R mRNA concentration in each sample was calculated from the optical density of the band and expressed as a percentage of that at diestrus.

\section{GnRH-R-binding assay}

Anterior pituitaries were homogenized with 10 $\mathrm{mM}$ Tris- $\mathrm{HCl}, \mathrm{pH} 7.6$, containing $1 \mathrm{mM}$ dithiothreitol, and the homogenate was centrifuged at 20,000 $\times \mathrm{g}$ for $20 \mathrm{~min}$. The resulting pellet was resuspended in the same buffer solution. The GnRH superagonist, [D-Ala ${ }^{6}$-des-Gly ${ }^{10}-\mathrm{GnRH}$-N-ethylamide (D-Ala ${ }^{6}$-EA, Peninsula Laboratories, Belmont, CA, U.S.A.) was radioiodinated and purified by high-performance liquid chromatography as previously described [11].

An amount of membrane preparation containing $100 \mu \mathrm{g}$ protein was incubated with ${ }^{125}$ I-labeled-D-Ala ${ }^{6}$-EA in the presence or absence of $100 \mathrm{nM}$ unlabeled D-Ala ${ }^{6}$-EA for $80 \mathrm{~min}$ at $4^{\circ} \mathrm{C}$. The reaction was terminated by tenfold dilution with ice-cold $10 \mathrm{mM}$ phosphate-buffered saline followed by filtration through a Whatman GF/C filter as described previously [12]. The amount of radioactivity attached to the filter was measured in a gamma counter at $70 \%$ efficiency.

\section{Hormone assay}

The concentrations of GnRH in the hypothalamic extracts were measured by a double-antibody radioimmunoassay as previously described [13]. The concentrations of $\mathrm{LH}$, follicle-stimulating hormone (FSH) and LH- $\beta$ in sera and anterior pituitary extracts were measured with a double-antibody radioimmunoassay kit provided by NIDDK (Bethesda, MA, USA), and were expressed in terms of the NIDDK reference standards rLH-RP-2, rFSHRP-1, and LH beta AFP-A805.

\section{Statistical analysis}

Data were represented as the mean \pm SEM. 
Statistical differences were analyzed by one-way analysis of variance followed by the StudentNewman-Keuls multiple comparison test.

\section{Results and Discussion}

\section{Amount of GnRH-R $m R N A$ and its binding capacity}

Figure 1A shows the pituitary GnRH-R mRNA concentrations as determined by Northern blot, as well as simultaneous measurements of radioiodinated-ligand binding by the receptor. A predominant mRNA species of approximately 5.0
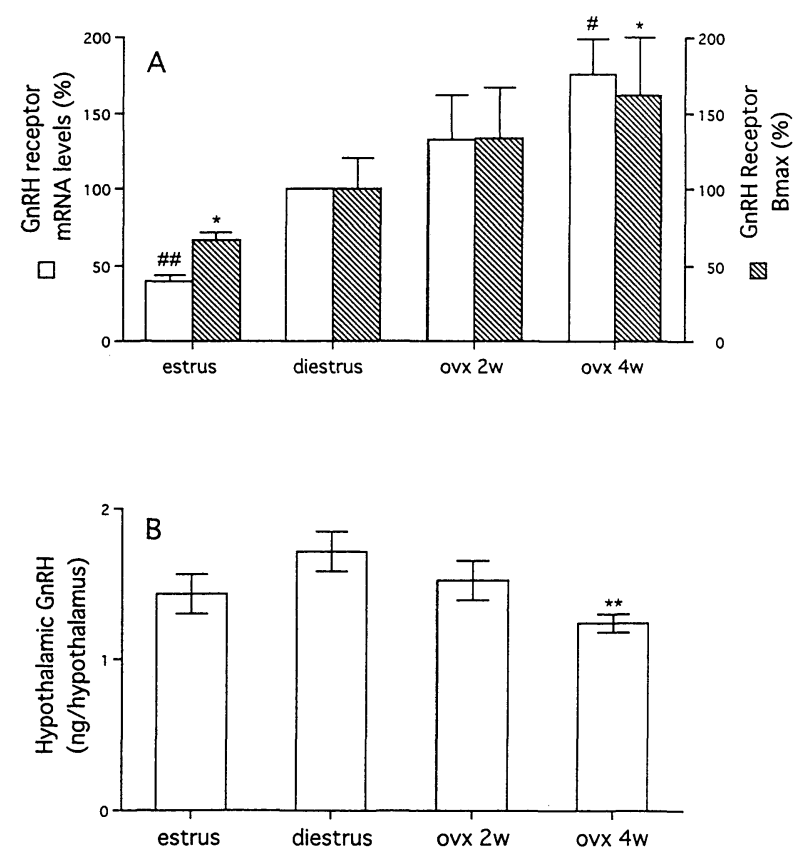

Fig. 1. A: Effect of ovariectomy on GnRH-R mRNA concentrations and GnRH-R binding capacity in the anterior pituitary. Anterior pituitaries were collected from rats at $1800 \mathrm{~h}$ on the days of estrus and diestrus, and at 2 (ovx $2 \mathrm{~W}$ ) and 4 (ovx $4 \mathrm{~W}$ ) weeks after ovariectomy. GnRH-R mRNA concentrations at each stage $(n=5$ for each group, open bar) and the receptor's binding capacity ( $n=4$ for each group, hatched bar) are expressed as a percentage of that at diestrus. B: Effect of ovariectomy on the GnRH concentration in the hypothalamus. Hypothalami were collected from rats at estrus and diestrus and at 2 (ovx $2 \mathrm{~W}$ ) and 4 (ovx 4W) weeks after ovariectomy ( $n=9$ for each group). Each bar represents SEM. ${ }^{*}$ and \# indicate a statistical significance of $P<0.05$ and ${ }^{* *}$ and \#\# a significance of $P<0.01 \mathrm{vs}$. diestrus. $\mathrm{kb}$ and other smaller and less abundant mRNAs of approximately 4.5 and $1.8 \mathrm{~kb}$ were detected in all groups examined. These bands were consistent with those of GnRH-R mRNA species reported previously [8]. GnRH-R binding at estrus was significantly lower (by 30\%) than that at diestrus, but its mRNA concentration decreased more (by $60 \%$ ). This result is consistent with other reports $[14,15]$, where a decline in GnRH-R mRNA was found to be significant after ovulation; but these studies did not also investigate ligand binding by GnRH-R. After ovariectomy, GnRH-R binding had increased by $30 \%$ at $2 \mathrm{wk}$ and by $70 \%$ at $4 \mathrm{wk}$. These changes paralleled receptor mRNA concentrations, which tendency is compatible with previous reports $[16,17]$.

Changes in GnRH-R mRNA concentrations during the estrous cycle may be the result of a rapid, short-term regulation that is distinct from the longterm effects of ovariectomy. These results indicate that transcriptional activity may be more intimately linked with GnRH-R binding in the long-term increase after ovariectomy than in the short-term regulation of the estrous cycle. The post-transcriptional mechanism may play a more important role in the short-term regulation of the estrous cycle. Ovarian factors may contribute to the prompt changes in GnRH-R binding during the estrous cycle via such post-transcriptional modification. Recently, Tsutsumi et al. reported that a rapid increase in GnRH-R binding in $\alpha \mathrm{T}_{3}-1$ cells is induced by altered mRNA activity without altering mRNA concentrations [18]. A better understanding of these phenomena awaits further elucidation of such post-transcriptional mechanisms.

\section{GnRH-R and concentrations of gonadotropins}

Ovariectomy caused an increase in serum concentrations of gonadotropins (Fig. 2). Many investigators have noted that the sensitivity of pituitary gonadotrophs to GnRH is not increased after castration and that the most likely cause of gonadotropin release is increased gonadotropin content in pituitary gonadotrophs $[1,19]$. Nevertheless, the present study demonstrates that this phenomenon could be attributed in part to an increase in the number of GnRH-R on the surface of pituitary gonadotrophs or increased $\mathrm{GnRH}$ release from the hypothalamus. Serum concentrations of LH and FSH and pituitary FSH had already 

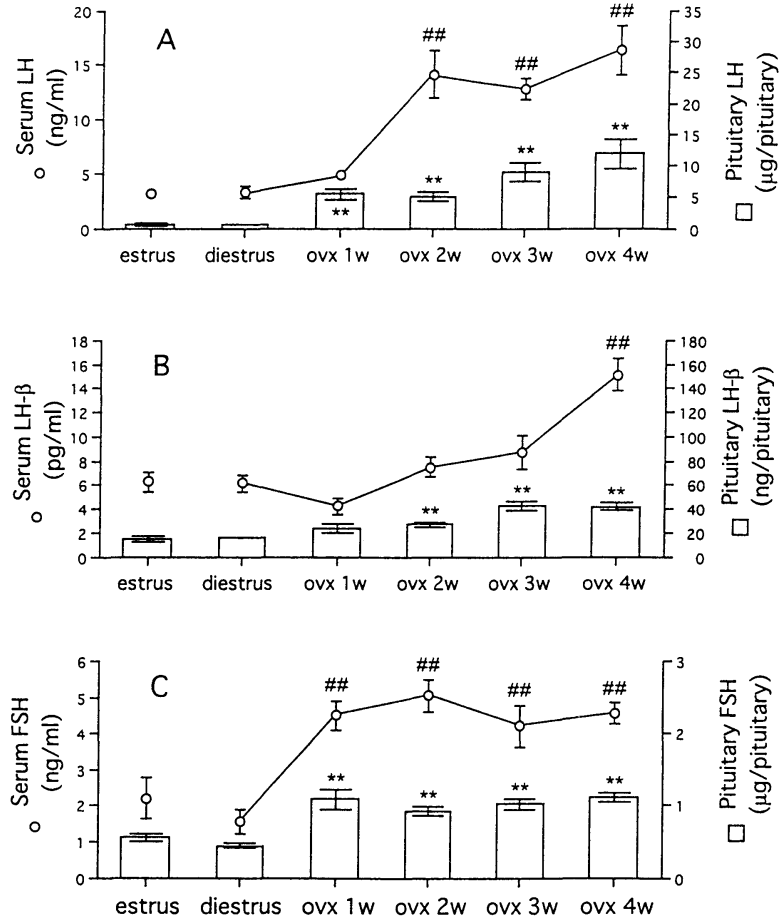

Fig. 2. Effect of ovariectomy on concentrations of LH (A), LH- $\beta$ subunit (B), and FSH (C) in the serum and anterior pituitary. Anterior pituitaries and sera were collected from rats at estrus and diestrus and at 1 (ovx 1W), 2 (ovx 2W), 3 (ovx $3 W$ ) and 4 (ovx $4 W$ ) weeks after ovariectomy ( $n=9$ for each group). Each bar represents SEM. ${ }^{* *}$ and \#\# indicate a statistical significance of $P<0.01$ vs. diestrus.

reached a plateau by 2 wk after ovariectomy. On the other hand, pituitary levels of $\mathrm{LH}$ and LH- $\beta$ subunit and serum concentrations of LH- $\beta$ were still increasing $4 \mathrm{wk}$ after ovariectomy. Di Gregorio et al. reported that serum FSH concentrations increased together with pituitary levels, but a rise in the serum $\mathrm{LH}$ concentration preceded an increase in its pituitary concentration [20]. Taken together, these data suggest that release and synthesis of FSH are synchronously regulated, but those of LH are differentially regulated in pituitary gonadotrophs after ovariectomy. In this study we note a parallel response of GnRH-R binding and pituitary $\mathrm{LH}$ and $\mathrm{LH}-\beta$ concentrations after ovariectomy. This suggests that the increase in GnRH-R may result in increased LH synthesis in pituitary gonadotrophs after ovariectomy.

The increase in GnRH-R after ovariectomy did not keep pace with the stimulation of LH and FSH release. Serum LH and FSH had increased to almost four times as much at $4 \mathrm{wk}$ after ovariectomy as at diestrus, whereas GnRH-R binding had increased less than doubled. These findings indicate that the ovariectomy-evoked activation of gonadotropin release is not solely the result of an increase in GnRH-R binding. GnRH in the hypothalamus had decreased significantly at $4 \mathrm{wk}$ after ovariectomy (Fig. 1B), suggesting that GnRH synthesis in the hypothalamus does not keep pace with its increased release after ovariectomy, resulting in a decline in hypothalamic stores. Indeed, analysis of hypophysial portal blood or blood harvested via push-pull perfusion revealed that GnRH release from the hypothalamus increases after ovariectomy [21, 22]. This evidence suggests that gonadotropin release is augmented by increased $\mathrm{GnRH}$ release from the hypothalamus. In spite of these lines of evidence, the argument for ovariectomy-stimulated biosynthesis of $\mathrm{GnRH}$ is not fully supported by studies on GnRH mRNA in the hypothalamus [23-25]. In addition to this controversial issue on the effect of ovariectomy on hypothalamic GnRH mRNA, we are now investigating the mechanism of the increase in $\mathrm{GnRH}$ release from the hypothalamus after ovariectomy.

\section{Acknowledgments}

The authors are indebted to NIDDK in NIH for rat LH, FSH, and LH- $\beta$ RIA kits.

\section{References}

1. Clayton RN, Solano AR, Garcia VA, Dufau ML, Catt KJ (1980) Regulation of pituitary receptors for gonadotropin-releasing hormone during the rat estrous cycle. Endocrinology 107: 699-706.

2. Savoy MR, Schwartz NB, Duncan JA, Marshall JC (1980) Pituitary gonadotropin-releasing hormone receptors during the rat estrous cycle. Science 209: 942-944.

3. Abbot SD, Naik SI, Clayton RN (1986) Dissociation between pituitary $\mathrm{GnRH}$ binding sites and $\mathrm{LH}$ response to GnRH in vitro. Mol Cell Endocrinol 48: 191-197. 
4. Eidne KA, Sellar RE, Couper G, Anderson L, Taylor PL (1992) Molecular cloning and characterisation of the rat pituitary gonadotropin-releasing hormone (GnRH) receptor. Mol Cell Endocrinol 90: R5-R9.

5. Kakar SS, Musgrove LC, Devor DC, Sellers JC, Neill JD (1992) Cloning, sequencing, and expression of human gonadotropin releasing hormone $(\mathrm{GnRH})$ receptor. Biochem Biophys Res Commun 189: 289295.

6. Weesner GD, Matteri RL (1994) Rapid communication: Nucleotide sequence of luteinizing hormone-releasing hormone (LHRH) receptor cDNA in the pig pituitary. J Anim Sci 72: 1911.

7. Ojeda SR, Wheaton JE, Jameson HE, McCann SM (1976) The onset of puberty in the female rat: Changes in plasma prolactin, gonadotropins, luteinizing hormone-releasing hormone (LHRH), and hypothalamic LHRH content. Endocrinology 98: 630638.

8. Kaiser UB, Zhao D, Cardona GR, Chin WW (1992) Isolation and characterization of cDNAs encoding the rat pituitary gonadotropin-releasing hormone receptor. Biochem Biophys Res Commun 189: $1645-$ 1652.

9. Cobianchi F, Wilson SH (1987) Enzymes for modifying and labeling DNA and RNA. Methods Enzymol 152: 94-110.

10. Cleveland DW, Lopata MA, MacDonald RJ, Cowan NJ, Rutter WJ, Kirschner MW (1980) Number and evolutionary conservation of alpha- and beta-tubulin and cytoplasmic beta- and gamma-actin genes using specific cloned cDNA probes. Cell 20: 95105.

11. Iwashita M, Hirota K, Izumi S-I, Chen HC, Catt KJ (1988) Solubilization and characterization of the rat pituitary gonadotrophin-releasing hormone receptor. J Mol Endocrinol 1: 187-196.

12. Loumaye E, Catt KJ (1983) Agonist-induced regulation of pituitary receptors for gonadotropin-releasing hormone. Dissociation of receptor recruitment from hormone release in cultured gonadotrophs. J Biol Chem 258: 12002-12009.

13. Iwashita M, Makino T, Arisawa M, Iizuka R (1982) Serum levels of immunoreactive LH-RF through pregnancy and parturition. Asia Oceania J Obstet Gynaecol 8: 297-304.

14. Bauer-Dantoin AC, Hollenberg AN, Jameson JL (1993) Dynamic regulation of gonadotropin-releasing hormone receptor mRNA levels in the anterior pituitary gland during the rat estrous cycle. Endocrinology 133: 1911-1914.

15. Funabashi T, Brooks PJ, Weesner GD, Pfaff DW
(1994) Luteinizing hormone-releasing hormone receptor messenger ribonucleic acid expression in the rat pituitary during lactation and the estrous cycle. J Neuroendocrinol 6: 261-266.

16. Kudo A, Park MK, Kawashima S (1994) In situ hybridization study of gonadotropin-releasing hormone $(\mathrm{GnRH})$ receptor mRNA in female rat pituitary gland during estrous cycle and after ovariectomy. J Reprod Dev 40: 149-158.

17. Kaiser UB, Jakubowiak A, Steinberger A, Chin WW (1993) Regulation of rat pituitary gonadotropin-releasing hormone receptor mRNA levels in vivo and in vitro. Endocrinology 133: 931-934.

18. Tsutsumi M, Laws SC, Sealfon SC (1993) Homologous up-regulation of the gonadotropin-releasing hormone receptor in alpha T3-1 cells is associated with unchanged receptor messenger RNA (mRNA) levels and altered mRNA activity. Mol Endocrinol 7: 1625-1633.

19. Leipheimer RE, Gallo RV (1983) Acute and longterm changes in central and pituitary mechanisms regulating pulsatile luteinizing hormone secretion after ovariectomy in the rat. Neuroendocrinology 37: 421-426.

20. Di Gregorio GB, Kile JP, Herring RH, Nett TM (1991) More rapid restoration of pituitary content of follicle-stimulating hormone than of luteinizing hormone after depletion by oestradiol-17 beta in ewes. J Reprod Fertil 93: 347-354.

21. Levine JE, Ramirez VD (1982) Luteinizing hormonereleasing hormone release during the rat estrous cycle and after ovariectomy, as estimated with pushpull cannulae. Endocrinology 111: 1439-1448.

22. Sarkar DK, Fink G (1980) Luteinizing hormone releasing factor in pituitary stalk plasma from long-term ovariectomized rats: Effects of steroids. J Endocrinol 86: 511-524.

23. Kelly MJ, Garrett J, Bosch MA, Roselli CE, Douglass J, Adelman JP, Ronnekleiv OK (1989) Effects of ovariectomy on GnRH mRNA, proGnRH and GnRH levels in the preoptic hypothalamus of the female rat. Neuroendocrinology 49: 88-97.

24. Roberts JL, Dutlow CM, Jakubowski M, Blum M, Millar RP (1989) Estradiol stimulates preoptic areaanterior hypothalamic proGnRH-GAP gene expression in ovariectomized rats. Brain Res Mol Brain Res 6: 127-134.

25. Toranzo D, Dupont E, Simard J, Labrie C, Couet J, Labrie F, Pelletier G (1989) Regulation of pro-gonadotropin-releasing hormone gene expression by sex steroids in the brain of male and female rats. $\mathrm{Mol}$ Endocrinol 3: 1748-1756. 